\title{
The Challenges Facing the Foreign Language Teacher Educator: A Proposed Teacher Education Model for EFL
}

Carol Goldfus

\begin{abstract}
As a result of the multi-cultural classroom in the 21st century, language teacher educators face new challenges; for example, young learners and those with language-based difficulties. In order to respond to these evolving needs, a new professional approach that combines theoretical knowledge with practical application is proposed. This approach targets what it is that teachers should know about literacy acquisition in at least two languages - a mother tongue and, in this case, English. The contribution of this proposed model to language education is to produce a teacher with declarative knowledge and research tools on the one hand, as well as the ability to cope with a heterogeneous classroom in a multicultural society on the other. This paper also intends to show how pre-service teacher education would benefit from an interdisciplinary approach with a combination of declarative knowledge and procedural knowledge with all teaching being 'science-based practice'.
\end{abstract}

Key words: Foreign language teacher education, Young learners, Pupils with dyslexia, Bilingual literacy, English as a Foreign Language

\section{Introduction}

$\mathrm{E}$ nglish is currently the language of worldwide communication. Thus, the work of teachers of English as a second/ foreign language is increasingly visible and the education of teachers for English as a Second/ Foreign Language (ESL/EFL) learners has gained prominence. This article describes the development of an interdisciplinary model of foreign language teacher education. This new approach to language education aims at producing teachers with declarative knowledge and research tools on the one hand and the ability to cope with a heterogeneous classroom in a multicultural society on the other.

Two distinct specific driving forces were behind the formation of this new model: The recognition of the place of foreign languages within a changing world (Costa, McPhail, Smith, \& Brisk, 2005), and the teaching implications derived from greater understanding of the brain and how it functions (Berninger, 2004). With the inclusion of learners with language-related disabilities, specifically, dyslexia, in both general education and foreign language classrooms, it has become clear that teacher education must embrace the new discipline of pedagogical neuroscience (Fawcett \& Nicolson, 2007) as well as the fundamentals of foreign language learning and teaching. Therefore, the emphasis in the model presented here is on incorporating current research in the area of language processing by the second language learner, what Nicol (2001) describes as "one mind- two languages."

The ultimate goal of foreign language teacher education lies in providing teacher education graduates with training in approaches to teaching literacy that they can use successfully with their 
students for the rest of their teaching life. Drawing on current research in the cognitive sciences, foreign language educators are beginning to see that the foreign language teacher must address the acquisition of literacy within the framework of both the learner's native language and the new language to be acquired. In essence, this could be called "bilingual literacy" in that it assumes that the underlying cognitive processes in one language are the same for others. Such an approach to foreign language learning and teaching has the potential to help language teachers proceed with a deep awareness and understanding of literacy development in both languages as well as the knowledge that the pupils' comprehension and verbal production is likely to be at a higher level in the mother tongue than in the foreign language. Thus, teaching would be targeted at the level of the foreign language acquisition displayed by the learner and take into account the fact that though it is not the learner's first language, many cognitive processes are already in place. Considered in this way, each language can be seen to contribute to the other language thus leading ultimately to a higher level of proficiency in both languages.

Inspired by the words of Vartan Gregorian (2001), who has argued that higher education's greatest challenge is to develop a new model for teacher education for the new century, I have focused on developing a new model which applies research from across the disciplines (de León, 2001 cited by Cohen and Horowitz, 2002). As Lawes (2003:22) writes, theory is often described as "nothing more than talking about practice. To re-establish the real unity of theory and practice, .... it is necessary to reverse contemporary fashion and emphasize theory over practice." Building on McCutchen and Berninger's (1999) dictum that "Those who know, teach well," I argue for a combination of theory and practice. As Cochran-Smith (2005) has proposed, this melding of theory with practice is a prerequisite for the teacher in "the new teacher education." In this article, the focus is on the foreign language teacher educator and the changes effected in the English department specifically.

In developing the proposed model, we posed many questions, the most important being: What does the foreign language teacher need in order to be an effective teacher in a world of globalization and multilingualism? Other questions addressed were: What should teachers know about the learning processes in literacy acquisition? What should teachers know about bilingual/foreign/ multilingual learners and language acquisition?

In what follows, I first present the challenges that need to be addressed in foreign language teaching and literacy acquisition. Then I move on to illustrate how these issues have been addressed in the proposed model by way of a description of five projects which illustrate the implementation of the model. The background, therefore, is extensive thereby flagging up the complexity of foreign language teacher education.

\section{Challenges in foreign language teaching and understandings of Literacy}

\section{New perceptions of foreign language teacher education}

Foreign language teaching, which has often been placed on the backburner as the 'stepchild' of education (Swaffar, 2003), can no longer be regarded as a peripheral department but, as English is the lingua franca and fluency is the key to success, the teaching of English as a foreign language has taken its place at centre stage. Around the world, monolingualism seems to be the exception rather than the rule. Countries such as England, Luxembourg and Canada have become multilingual, and, of course, multiple languages can also be heard in the schools of these countries. Geva (2005) notes that cities like New York, London, and Toronto, now provide services to children from as many as twenty-seven different language groups.

The increasing number of English Language Learners (ELL) (Klinger, 2006) in the schools as a result of migration has created a new group of learners whose presence in turn requires rethinking aspects of teacher education (Costa, McPhail, Smith \& Brisk, 2005). In the European Union, for example, some countries have made provision for the teaching of a foreign language at the primary school level, while others are in the process of making important decisions regarding the introduction of foreign languages into the curriculum (Raya, Faber, Gewehr, Peck, 
2001). However, most teachers are not adequately prepared to teach students where English is the language of the country but not the mother tongue of the pupils. In addition, there is a problem where the mother tongue of the pupils differs from English in both orthography and directionality. As a result of these international issues, it seems essential that determining ways of addressing the problems of (1) diverse populations and (2) multilingual and multicultural settings become integral to curriculum and instruction in teacher education.

\section{Theory versus practice}

As in so many fields, developing a bridge between theory and practice is a persistent problem. In the field of foreign language teaching, Swaffar (2003) suggests that practice has substituted for theory and the result is a resounding emptiness and a discipline in crisis. It has become clear that we need something other than a recipe approach to teaching skills, grammar, and vocabulary; we must acknowledge that teaching language teaching cannot be effective without content: "If language teachers do not even begin to have some understanding of educational and applied subject theory, they will be mere technicians and feel themselves to be such" (Lawes, 2003:27). Thus, there is a need to re-define professional practice in light of a new type of teacher education (CochranSmith, 2005). The 'scientist-practioner approach' (Berninger et al. 2004), in which teachers study their own practice against a backdrop of relevant research represents one way in which teacher education might evolve.

\section{Teaching Reading Proficiency}

Another important issue that needs to be addressed relates to fluency and proficiency in reading. Teaching reading has become the focus of teacher education in recent years as increasingly research is being carried out on effective instructional practices. In the area of bilingual education, Cohen and Horowitz (2002) suggest that knowing how bilingual learners acquire literacy in two languages will influence the field of reading comprehension instruction. They ask the question, "what should teachers know about bilingual learners and the reading process in order to prepare effective teachers for the new century?"
A similar question is being asked regarding the foreign language situation. What is it that teachers need to know and do in order to succeed in teaching reading processes that consist of both decoding and comprehension? Now that second language reading instruction has gained in impetus, a research base must be established "that can facilitate productive innovations in second [and/ or foreign] language reading instruction"(Koda, 2005:3). Of primary concern are issues such as the place of memory in learning to read and write and in the enrichment of vocabulary, the complexity of reading comprehension and writing, and the storage and retrieval of facts. Thus, it has become evident that language teaching should now be geared to understanding how language is processed in the brain (Schumann et al. 2004; Berninger \& Richards, 2002).

\section{New perceptions of literacy}

Over the past ten to fifteen years, the meaning of the term "literacy" has shifted from basic reading and writing skills to the acquisition and manipulation of knowledge. The concept of literacy, defined as the ability to create and interpret meaning through texts (Chafe, 1994; Chafe \& Danielewicz, 1987; Kern, 2002), and characterized by the availability of multiple linguistic resources, by the ability to consciously access one's own linguistic knowledge and to view language from various perspectives (Goody \& Watt, 1968; Olson, 1991; Ong, 1992; Ravid and Tolchinsky, 2002), has become an international issue and lies at the core of 'any curriculum designed to teach a foreign language' (Swaffar, 2004).

Theories of cutting-edge research on literacy acquisition present a framework for understanding the nature of language processing and include more than just learning to decode but demands complex reading and writing skills in order to function in today's information age. Furthermore, the term 'literacy' has been extended to include electronic texts that focus primarily on written texts and on the processes involved in reading and writing (Sullivan, 2002). Simultaneously, there has been a significant shift in understandings of reading proficiency, particularly in research into how readers of languages employing nonalphabetic writing systems develop reading 
proficiency (Everson, 2002).

Recent research has shown that sound theoretical knowledge is essential to the foreign language teacher (Moats, 2009) and the development of this knowledge must begin at the start of the initial teacher training (ITT) (Lawes, 2003). Hence, proficiency in a foreign language can no longer be restricted to the ability to speak. On the contrary, literacy and proficiency in a language demands the ability to read and write fluently in the mother tongue and in at least one other language. This, in turn, relates to new knowledge about how the brain works.

\section{The brain and language learning}

The last decade of the twentieth century has been called the 'decade of the brain'-a period during which, with the participation of healthy individuals of all ages and with the benefit of sophisticated equipment such as the functional magnetic resonance imaging (fMRI) and magnetoencephalography (MEG), rigorous scientific research began to unveil the complex workings of the brain. Using these sophisticated imaging techniques to monitor the brain activity of children and adolescents while they are reading, writing and speaking has provided exciting opportunities to learn about the learning processes and has brought brain research into the educational setting.

Frith (1997, 2002) theorizes that there are three underlying processes involved in learning, namely, the biological level, the cognitive level and the behavioural level. The latter level is the one that most teachers are familiar with. It is here that progress is assessed by classroom testing as well as those high stakes testing situations where results demonstrate whether something has been learned and whether the required standard has been attained. According to Frith's basic causal modeling (1997), cognitive abilities underlie observable behaviour and these are based on neural systems in the brain. The chain of causal links from the brain, to the cognitive abilities to behaviour has to relate to the context of the environment thereby addressing the nature/ nurture interactions.

This current research and theory on the way the brain works and the implications of this work for teaching learning has the potential to significantly impact teacher education in ways that could lead to an "evolution" of the field-an evolution that acknowledges that preparing teachers for a changing context has to include an understanding of brain research and its implications for teaching and learning. Such change could result in the development of a generation of new teachers who are scientist-practitioner educators able to create optimal learning environments for all students (Berninger, Dunn, Lin, \& Shimada, 2004).

\section{Learning disabilities and foreign language acquisition}

As early as the early 1970 seventies, Dinklage, (1971) pointed out that the foreign language problem was as much a problem of pedagogy as it was a learning difficulty. In recent years, teaching a foreign language to students with language learning disabilities has been called the "ultimate foreign language challenge" (DiFino and Lombardino, 2004; Sparks, Schneider and Ganschow, 2002). The reason has to do with the ways in which instruction of second language learners and of children with language learning difficulties are handled in schools.

Although alternative multi-sensory approaches such as the Orton Gillingham method, from Alpha to Omega, the Hickey method, and the LCDH all relate to teaching learning-disabled students how to decode, and research has shown that students with learning disabilities learn how to decode by using a multi-sensory approaches (Ganschow and Meyer, 1988; Goulandris, 2003), learning disability experts are rarely prepared to teach foreign language and foreign language instructors are rarely prepared to address the problems that are associated with learning disabilities. Hence, foreign language instructors often have difficulty teaching those learning-disabled students who are in their classrooms. As DiFino and Lombardino, (2004:391) write, "an enormous void exists in this area particularly with respect to the development of alternative methodologies for facilitating the success of students with learning disabilities in learning an L2." 


\section{Responding to the challenges of education today: towards a new professional model}

\section{A new model - bilingual literacy}

The proposed model, "One brain - two languages: theory, research and professional development" places English as a foreign language within the larger framework of literacy acquisition and language proficiency in at least two languages, the mother tongue and the foreign language and is manifested in 'bilingual literacy,' a term I have coined to address the situation where the levels of proficiency (attainment) of each language are at different levels: the mother tongue being more proficient than the foreign language, but also recognizing that the underlying cognitive processes for language learning are the same. This approach to foreign language acquisition builds on current research in bilingualism (Nicol, 2001) and assumes that "literacy is an extension of language learning to print which involves more than decoding" (Westby, 2002:73). Language learning involves a multitude of complex cognitive processes taking place in the brain (Berninger, 2004).

Bilingual literacy involves knowledge of both mother tongue development as well as foreign language acquisition. Therefore, teacher preparation, for example in reading, should include core requirements in a) conceptual foundations of literacy development, b) knowledge of the structure of language (i.e. phonetics, phonology, orthography and its relationship to sound and meaning, syntax, and text structure) and c) supervised practice in teaching literacy (reading, writing, speaking - formal and informal speech). It is argued that such theoretical courses are a crucial step in preparing teachers for literacy learning. This knowledge base is required for any language, regardless whether the language being taught is a first, second or third language. For example, the foreign language pre-service students learn how to teach beginning reading in English while the mother tongue teachers learn how to teach the mother tongue but the theoretical background has been provided to both cohorts of pre-service students.

Developing a new pre-service teacher preparation program in building the new structure for foreign language teacher education, five projects were developed and are being studied. The first project involved developing proficiency guidelines and assessment tools for determining students' levels in English. This involved the standardization of our entry level criteria as well as raising our exit level criteria. The aim of both is to enhance the capabilities of our graduates and provide a high level academic programme based on clearly defined guidelines. Such criteria have enabled us to formulate objectives for each stage of our program from the first year entry level through the fourth year exit level and serve as a basis for development of proficiency examinations to be administered at the end of the degree.

A second project investigated the effectiveness of the theoretical, content-based courses vis-a-vis their practical application. In order to upgrade English teacher education, promote pre service teachers' linguistic sensitivity, and improve their teaching skills, English teacher trainees were required in their first year to take various courses in Applied Linguistics. As a means of giving them a sense of what language is, and how language is systematically structured as well as raising their sensitivity and awareness to phenomena in language, these pre-service teachers began in their first year to first learn and then practice the inherent features of language and the four language domains: phonetics and phonology, morphology, syntax and semantics.

In their second year, they took more advanced courses in applied linguistics including courses in first language acquisition, second language acquisition and learning, language variation, and change and contrastive analysis. By the end of the second academic year, we hoped that the students should have a solid understanding of phenomena in language evolution, acquisition, and learning. They should comprehend the relationship between theory and practical teaching.

We reasoned that having acquired background theoretical knowledge in language and linguistics, third-year students would be familiar with up-todate studies in applied linguistics and are ready to undertake courses in later language development and literacy and learn and practice the principles of text analysis and productive language measures 
(Berman \& Ravid, 2006). In this way, they would acquire the knowledge and tools to assess language and thereby improve their teaching skills.

The fourth year, during which students complete an internship in the field, was designed to provide pre-service students with experience of the relationship between research and practice. They were to take advanced courses in second language research methods, and, under the supervision of their lecturers, conduct a study in their EFL classes. Pre-service students would learn to evaluate L2 knowledge in two perspectives: grammar and literacy which together provide a rich picture of learners' textual abilities in the second language. These pre-service students would practice analyses in different genres (i.e., expository vs. narrative) and in different modalities (i.e., written vs. spoken). They would learn how to form research question(s) and hypotheses, collect data, and analyze them. This evolution from practitioner to researcher and then from researcher to practitioner would qualify them as professional EFL teachers and researchers.

The third project addresses the issue of methodology. Thus the field of TEFL (Teaching English as a Foreign Language), the applied science, was included in the new professional model as this area provides the pre-service students with the practical application of the theory. This aspect of teacher education involves hands-on workshops where the pre-service students develop teaching materials at the elementary and secondary school levels. In addition, courses in this field include formal and informal testing thus combining theory with practical knowledge. The interface of applied linguistics with the field of TEFL/TESOL provides the backbone to the theory cum practice combination.

The fourth project provided another important dimension of language. It introduced literature, cinema, and the arts to pre-service students so as to broaden their horizons and knowledge of culture. It exposed them to the different genres of narrative, poetry, and drama and includes all expressions of language. The rationale for this project was that language is culture-based, thus, we cannot train teachers without having provided an understanding of the complexities of the cultures behind the language.
The fifth project applied specialized training in learning disabilities and EFL. As noted earlier, the increased presence of children with learning difficulties in the regular classroom and the inclusion of children who have dyslexia, attention difficulties, and difficulty in processing language in foreign language classes requires that teacher educators provide their students with critical information and practice in the area of special education. At the end of four years, pre-service students should be able to attend to a child with learning disabilities in any EFL classroom from elementary school to the secondary school.

The elementary school teacher should be knowledgeable about phonological awareness and how to teach reading based on a phonics, multisensory approach. The emphasis of preparation of teachers for the elementary school should focus on basic decoding skills, word recognition and vocabulary development, the strengthening of working memory, storage and retrieval together and should also provide intensive training in a multi-sensory, multidisciplinary approaches to teaching EFL.

The secondary school teacher should concentrate on reading comprehension as a higher level cognitive processing activity that includes knowledge of working memory, attention, and metacognition. Intensive training should be given to understanding language processing difficulties as well as $\mathrm{ADD} / \mathrm{ADHD}$, a learning difficulty that is not language specific.

By the end of their fourth year, those students who are carrying out a supervised internship should be able to apply what they have learned in the classroom, adapt theory to practice, develop materials to be used in a heterogeneous classroom setting, assess their students' knowledge, and then return to the college classroom for presentation, discussion, and evaluation.

\section{Professional development of staff}

Any curriculum plan shouldacknowledgestudents' specific needs, expectations, proficiency levels and attributes. Moreover, it should account for specific institutional expectations and constraints (Woodward, 1991) and should make provision for ongoing professional development. On-going, in- 
service training in small interest groups should be conducted so as to 'retrain' veteran teachers and absorb new faculty. In our setting, we have moved slowly. Every course is being researched so as to provide an understanding of both the pre-service students' learning, the development of the academic course, as well as the effect of such action research on the lecturer developing the courses. In many cases, they have had to reassess their courses and to update themselves in their field. New faculty members with expertise and doctoral study in one of the program fieldslinguistics, special education, foreign language instruction, and literacy-have been recruited. Teaching loads have been adjusted to acknowledge the greater connections expected between theory and practice within the college classroom.

\section{Impact of the changes}

In a questionnaire asking the lecturers to reflect over the changes that have taken place over the last five years, (appendix 1) the following comments illustrate these changes and professional development.

\section{Proficiency courses}

'I have witnessed the immense improvement in student writing throughout the years. Very weak students who were unable to write a single sentence have become proficient essay writers. The writing and grammar courses in the last few years have produced excellent results.'

\section{Literature and cinema}

'The students love these courses and have become acquainted with a variety of new texts and teaching strategies that can be used in the classroom. Following our departmental discussions these courses have undergone quite a change. The literature and cinema courses no longer have a purely academic character - we now put more emphasis on grammar and writing as well as on the relevance of these academic studies to the practical work in the field.'

In a question: "I would like to know the impact of changes in the department on the faculty staff. Are you teaching differently? Please explain and give examples," these are a couple of comments:

'During the past five years my teaching strategies have changed significantly. Thanks to Carol's insistence on excellence and on upto-date research, I have made an extra effort to become acquainted with the latest research in my discipline. I have also understood the importance of an interdisciplinary approach to teacher education, and I integrate knowledge and strategies from different fields during my lessons (psychology, education, literature, philosopy and media studies).'

Other members of staff commented on the course Cognitive Neuroscience and Language Acquisition given to the staff as in-service training during the year,

'I have gained a deeper awareness of the links between the brain systems and the components of literacy. Having been exposed to examples of effective instructional practices in literacy based on brain research has given me ideas of addressing my teaching from the point of view of the higher cognitive skills involved in language learning and teaching.'

To the question whether the students are working differently than in the past, one answer said that the EFL/LD courses endow them with knowledge and heighten their awareness of the special needs of those learner populations who are LD students and give them tools to address the needs of this population of pupils.

'However, as far as proficiency is concerned, more work needs to be done to promote, assess and determine the EFL proficiency of our students who are future teachers of English.'

\section{About the students' reactions}

'The students often complain about the number of assignments and their scope (as students do); however, most of them are happy with the courses given and pleased with the departmental staff and program.'

\section{What do the graduates say?}

'I have spoken to quite a few students who graduated this year..... They claim that they have undergone an enormous personal and professional change during their four years in the department. In spite of their complaints about the long hours, the difficulty of the material studied and the 
numerous papers and exams to be written, they are pleased with their achievements and feel that they have experienced personal growth as well as professional excellence."

\section{One third year student studying combined special education and English wrote}

'I would like to thank you for well-planned and effective courses in the English Department..... I feel that the material which I have learned and will learn have helped me in the field. The courses do not repeat themselves, are very interesting and expand my horizons. The lecturers are pleasant, helpful and give me a good feeling about myself and the subject that I have chosen to work and invest in for the rest of my life.'

Assessment of both teacher performance, curriculum development and research-supported instruction in teaching practice is still underway. While we can argue that many boundaries between disciplines have been broken down and that our graduates will go into the field as leaders and implementers of new ways of teaching, it is still too soon to make such claims. Further research assessing the program, implementing and monitoring the students' performance in the field is necessary.

\section{Conclusion}

The ultimate goal of the program described in this paper has been to raise standards of teaching and teacher preparation to meet the challenges of education in the new global setting. In this paper, I described five projects as part of a new model in which the teaching of English as a foreign language is based on a concept of evolution that requires a dual approach to teacher education. The first part of this approach calls for new methods for pre-service teacher education and continuing professional development; the second part calls for an understanding of the naturenurture interactions in learning, the complexities of assessing language proficiency and the importance of understanding the diverse abilities of the student populations. Our intent and goal in adopting an the interdisciplinary approach like that described above is that new teachers in the field will not only know the target language, but they will also be able to adapt their knowledge to the heterogeneity of the classroom, understand diversity and be able to cope in the complex, fast world of the present.

In essence, a good teacher needs a 'barrelful' of knowledge to take out a 'cupful' and present the right 'spoonful' to the students.

However, these changes do not take place in a vacuum, but within contextual changes in the college. A case has been made that by combining many theoretical courses, all pre-service language teachers will be provided with a solid basis for excellence in language teaching. In this way, English can no longer be a peripheral department but has become an integral part of the new model of teacher education (Cochran-Smith, 2005).

\section{The Author}

Carol Goldfus received her doctorate in Applied Linguistics from the University of Birmingham, England. She is currently Head of the Adam Research Center for Language Abilities and Multilingualism, Levinsky College of Education in Tel Aviv, and until recently, was Head of the English Department there. Her research interests include cognitive intervention in adolescents with learning disabilities, the development of metacognition, reading comprehension and memory. Within the field of teacher education, she has developed a model for the new professionalism of the foreign language teacher educator. Furthermore, she is developing a practical application of brain research for teaching and learning. Carol is an executive member of the International Academy of Research into Learning Disabilities.

\section{References}

Anders, P. L., Hoffman, J. V., \& Duffy, G. (2000). Teaching teachers to teach reading: paradigm shifts, persistent problems, and challenges. In: M. L. Kamil, P. B. Mosenthal, P.D. Pearson \& R. Barr (Eds.), Handbook of reading research, III, (pp. 719-742). Mahwah: Erlbaum.

Berman, R.A. (Ed.). (2004). Language development across childhood and adolescence. Amsterdam: John Benjamins Publishing Company.

Berninger, V.W., Dunn, A., Lin, S-J. C., \& Shimada, S. (2004). School-evolution: scientist-practitioner educators creating optimal learning environments for all students. Journal of Learning Disabilities, 37 (6), 500-508.

Berninger, V. W., \& Richards, T. L. (2002). Brain literacy for educators and psychologists. New York: Academic Press.

Berninger, V.W. (2004). The reading brain in children 
and youth: a systems approach. In Wong, B. (Ed.), Learning about learning disabilities (pp. 197-248).

London: Elsevier Academic Press.

Blakemore, S. J., \& Frith, U. (2005). The learning brain. Oxford: Blackwell Publishing.

Cameron, L. (2003). Challenges for ELT from the expansion in teaching children. ELT Journal, 57 (2), 105-111.

Chafe, W. (1994). Discourse, consciousness, and time: the flow and displacement of conscious experience in speaking and writing. Chicago: University of Chicago Press.

Chafe, W., \& Danielewicz, J. (1987). Properties of spoken and written language. In: R. Horowitz \& S. J. Samuels (Eds.), Comprehending oral and written language (pp. 83-113). San Diego: Academic Press.

Cochran-Smith, M. (2005a). The new teacher education: for better or for worse. Presidential address, AERA Annual Meeting, Montreal, Canada.

Cochran-Smith, M. (2005b). Teacher education and the outcomes trap. Journal of Teacher Education, 56 (5), 411-417.

Cohen, A. D., \& Horowitz, R. (2002). What should teachers know about bilingual learners and the reading process? In: J.H. Sullivan (Ed.), Literacy and the second language learner (pp. 29-54). Connecticut: Information Age Publishing.

Costa, J., McPhail, G., Smith, J., \& Brisk, M. E. (2005). The challenge of infusing the teacher education curriculum with scholarship on English language learners. Journal of Teacher Education, 56, pp. 104-118.

DiFino, S.M., \& Lombardino, L.J. (2004). Language learning disabilities: the ultimate foreign language challenge. Foreign Language Annals, 37 (3), pp. 390-400.

Dinklage, K. (1971). Inability to learn a foreign language. In G. Blaine and C. McArthur (Eds.), Emotional problems of the students (pp.185-206). New Your:Appleton-Century-Crofts.

Everson, M. E. (2002). Theoretical developments in reading Chinese and Japanese as foreign languages. In: J. H. Sullivan (Ed.), Literacy and the second language learner (pp. 1-16). Connecticut: Information Age Publishing.
Faber, P., Gewehr, W., Raya, M.J., \& Peck A.J. (Eds.). (2001). Effective foreign language teaching at the primary level. Frankfurt am Main: Peter Lang.

Fawcett, A. J., \& Nicolson, R. I. (2007). Dyslexia, learning and pedagogical neuroscience. Developmental Medicine \& Child Neurology 2007(49), pp. 306-311.

Frith, U. (1997). Brain, mind and behaviour in dyslexia. In: Hulme, C. \& Snowling, M. (Eds.). Dyslexia, Biology, Cognition and Intervention (pp. 1-19). London: Whurr Publishers.

Frith, U. (2002). Resolving the paradoxes of dyslexia. In: Reid, G. \& Wearmouth, J. (Eds.), Dyslexia and literacy, theory and practice (pp. 45-68). West Sussex: John Wiley and Sons.

Ganschow, L., \& Myer, B. (1988). Profiles of frustration: second language learners with specific learning disabilities. In: J. Lalande (Ed.), Shaping the Future of Foreign Language Education (pp. 32-53). Lincolnwood, IL: National Textbook.

Geva, E. (2005). The development of literacy skills in normally developing and at-risk L2 Learners: From research to practice. Keynote speaker at Third International Multilingualism and Dyslexia Conference, Limassol, Cyprus.

Goody, J., \& Watt, I. (1963). The consequences of literacy. Contemporary studies in society and history, 5, pp. 304-345.

Goulandris, N. (2003). Dyslexia in different languages: cross linguistic comparisons. London: Whurr Publishers.

Gregorian, V. (2001, July 6). How to train - and retainteachers. The New York Times, p. 17A.

Kern, R. (2002). Reconciling the language-literature split through literacy. ADFL Bulletin, 33 (3), 20-24.

Koda, K. (2005). Insights into second language reading. A cross linguistic approach. New York: Cambridge University Press.

Lawes, S. (2003). What, when, how and why? Theory and foreign language teaching. Language Learning Journal, Special Edition, 28, pp. 22-28.

McCutchen, D., \& Berninger, V. W. (1999). Those who know, teach well: helping teachers master literacy-related subject-matter knowledge. Learning Disabilities Research and Practice, 14 (4), 215-226. 
Moats, L. (2009). Still wanted: teachers with knowledge of language. Journal of Learning Disabilities, 42(5), pp. 387-391.

Nicol, J.L. (Ed.). (2001). One mind, two languages: bilingual language processing. Oxford: Blackwell Publishers.

Olson, D.R. (1991). Literacy and objectivity: the rise of modern science. In: D. R. Olson \& N. Torrance (Eds.), Literacy and orality (pp. 149-164). New York: Cambridge University Press,

Ong, W.J. (1992). Writing is a technology that restructures thought. In: P. Downing, S. D. Lima, \& M. Noonan (Eds.), The Linguistics of Literacy (pp. 293-319). Amsterdam: John Benjamins.

Schumann, J.H., Crowell, S.E., Jones, N.E., Lee, N., Shuchert, S.A., \& Wood, L.A. (2004). The neurobiology of learning. Mahwah, New Jersey: Lawrence Erlbaum Associates.

Shaywitz, S. (2003). Overcoming Dyslexia. New York: Alfred A. Knopf.

Sparks, R.L., Schneider, E., \& Ganschow, L. (2002). Teaching foreign (second) languages to atrisk learners: research and practice. In: J. H. Sullivan (Ed.), Literacy and the Second Language
Learner (pp. 55-84). Connecticut: Information Age Publishing.

Sullivan, J.H. (2002). The second language educators' challenge: learning about literacy. In: J. H. Sullivan (Ed.), Literacy and the Second Language Learner (pp. ix-xii). Connecticut: Information Age Publishing.

Swaffar, J. (2003). Foreign languages: a discipline in crisis. ADFL Bulletin, 35, pp. 20-22.

Westby, C. (2002). Beyond decoding: critical and dynamic literacy for students with dyslexia, language learning disabilities (LLD), or attention deficit-hyperactivity disorder (ADHD). In: Butler, K.G. \& Silliman, E. R. (Eds.), Speaking, reading, and writing in children with language learning disabilities: new paradigms in research and practice (pp. 73-108). Marwah: Lawrence Erlbaum Associates.

Woodward, T. (1991). Models and metaphors in language teacher training: loop input and other strategies. In: Gairns, R. \& Williams, M. (Eds.), Teacher training and development. New York: Cambridge University Press. 


\section{Appendix I \\ “New Model” Questionnaire}

\section{Dear Teachers}

During the last few years, we have been developing a model of "The New Professionalism of the Foreign Language Teacher Educator "which has led, among other things, to presenting a new program to the Council for Higher Education. In reflecting over the changes that have taken place as well as your contribution to the department, whether you are a new teacher adding to the professionalism, or a veteran, whose courses have undergone changes, I would like you to reflect on the following questions.

\section{Impact on faculty staff}

1. What do you say about the five projects? Please explain in detail.

(i) Proficiency courses

(ii) Literature and Cinema

(iii) Applied Linguistics

(iv) TEFL

(v) EFL/LD

2. I would like to know the impact of changes in the department on the faculty staff. Are you teaching differently? Please explain and give examples.

3. Impact on the students

1. Are the students who have gone through this program working differently from those who graduated earlier? Please explain and give examples. 
2. What do the students say about the program? Please explain and give examples.

3. What do the graduates say? Please explain and give examples.

4. What do employers say? Please explain and give examples. 